NBER WORKING PAPER SERIES

\title{
TAXES AND OWNERSHIP STRUCTURE: \\ CORPORATIONS, PARTNERSHIPS \\ AND ROYALTY TRUSTS
}

E. Philip Jones

Robert A. Taggart, Jr.

Working Paper No. 1441

\author{
NATIONAL BUREAU OF ECONOMIC RESEARCH \\ 1050 Massachusetts Avenue \\ Cambridge, MA 02138 \\ September 1984
}

The research reported here is part of the NBER's research program in Financial Markets and Monetary Economics. Any opinions expressed are those of the authors and not those of the National Bureau of Economic Research. 
Taxes and Ownership Structure:

Corporations, Partnerships and Royalty Trusts

\section{ABS TRACT}

This paper investigates the effect of taxes on the equilibrium ownership structure of productive assets. Ownership structure includes the traditional choice between debt and equity financing, but also the larger choice between corporate and partnership forms.

A key feature of these alternative forms is that corporations are subject to taxation at both the corporate and investor levels, whereas partnerships are not. At the same time, depreciation and interest tax shields are taken at the corporate tax rate for corporate assets and at investors' tax rates for partnership assets. We find that assets endowed with excess non-interest tax deductions are best held in partnership form by high tax bracket investors. Assets whose allowed deductions are low enough to generate a net tax liability in corporate form are best held as partnerships by low tax bracket investors. All other assets are held in the corporate sector and are financed in a manner consistent with Miller's (1977) capital structure equilibrium.

We argue that our analysis illuminates the tax aspects of such transactions as mergers and sales or spin-offs of corporate assets to partnerships and royalty trusts. We also show that our results afford a simple characterization of the lease or buy decision.

E. Philip Jones

Harvard Business School

Soldiers Field Road

Boston, MA 02163

(617) $495-6422$
Robert A. Taggart, Jr. Boston University School of Management 704 Commonwealth Avenue Boston, MA 02215 (617) 353-4158 


\section{Introduction}

The corporate form has many well-known benefits. By separating ownership from management, it allows productive assets to be managed by those who are best qualffied, regardless of their personal wealth or attftudes toward risk. The corporate form also factlitates the exchange of ownership clatms among investors, and in so doing it allows the management of the assets to proceed continuously, independent of the Ifves or fortunes of individual owners.

Despite these benefits, however, many productive assets are owned by noncorporate business entitles, such as partnerships. This fact has received spectal emphasis in recent years as corporations themselves have often been instrumental in shifting assets outside the corporate sector (see Cooper, 1984). Transactions in which corporate assets are sold to an Investor group and then leased back have been common for some time. A more recent variation on this theme is Metromedia's outright sale in 1982 of 41,000 advertising billboards to wealthy investors through a Ifmited partnership (Abrams, 1984). Another example, which has attracted considerable public attention, is the spin-off of natural resource properties to be held directly by investors through a royalty trust. This transaction has been carried out by Mesa Petroleum, Masonite and other corporations (Cooper, 1984).

The prevalence of. such activity suggests the need for a theory of ownership structure. Finance theorists have focused their attention on the mix of debt and equity claims that corporations should issue to finance their ownership of productive assets, but this is only a part of the problem. Coming prior to the financing question is the issue of whether or not a given asset should be held in corporate form at all. 
The need for a broader theory, encompassing the choice of organizatlonal form as well as the financling $m 1 x$, has been recognized in recent papers by Fama and Jensen $(1983 \mathrm{a}, \mathrm{b})$. They devote part1cular attention to the relative severfty of Incentive, or agency, problems among corporations, partnersh1ps, mutuals and other forms.

The purpose of our paper 1s to explore another aspect of the same question, namely taxation. It is widely recognized that the corporate form entalls double taxation, whlle alternatives such as partnerships and royalty trusts do not. However, the asset market equilibrium implications of this difference in tax treatment have not been fully analyzed. In particular, we are 1nterested in finding out which tanglble assets should be held in corporate form and which in partnership form. We also analyze which investors will hold partnership shares in equilibrlum and which will hold corporate securfties.

We abstract from uncertainty in order to eliminate all agency problems and focus attention squarely on tax considerations. In Section 2 , we conslder a simple one-pertod model, which allows us to completely characterize the allocation of tanglble assets among partnerships and corporations, as well as the financting of those assets held in the corporate sector. We show that assets endowed with excess tax deductions are better held in partnership form by hlgh tax bracket investors. Simflarly, assets that would generate a net tax llabllity if owned by a corporation are better held in partnershlp form by low tax bracket 1nvestors. All other assets are held in the corporate sector and are flnanced in a manner consistent with Mfller's (1977) capital structure equiifbrium. 
In Section 3, we consider asset market equilibrium in a multiperiod setting. Under the assumption that assets can be costlessly traded or converted to another ownership form, we obtain results that are analogous to those of the one-perlod case. The force driving the allocation of assets to corporate and partnersh1p form in the multiperlod case is the desire to minimize total taxes in every period.

The next three sections are devoted to applications and elaborations of our basic analysis. In Section 4 we show that a particularly simple characterization of the lease-or-buy decision emerges as a byproduct of our results on optimal asset ownership. In Section 5 we show how a given asset may naturally progress through different ownership forms as its cash flows and depreciation allowances evolve over the course of its useful 11fe. In Section 6, we show that in an environment of capital gains and recapture taxes, changes in corporate ownership, through mergers and acquisitions or sales of assets, are an alternative to changes in ownership form for minimizing taxes.

In Section 7 we briefly summar1ze our results and suggest some further extensions.

\section{The One-Period Case}

2a. The structure of the model and the definition of equilibrium

The optimal packaging of tanglble assets can be 1llustrated most readily for the one-period case. This case entails finite asset life, which we later show to be an 1mportant element of the partnership form's attractiveness, but at the same time it avoids the complication of multiperiod term structure 1ssues. We will also argue in Section 3 that, 
when assets can be costlessly repackaged, the multiperiod case collapses, with ofinor modifications, to the one-perfod case.

We assume an exogenous supply of tangtble assets at the beginning of the perfod. Each asset generates an identical pre-tax cash flow, $C(>0)$, at the end of the period. Any production technology using these assets exhibits constant returns to scale, so we can discuss the optimal packaging of any one of these assets in isolation from the others. For. each asset, a, the owner ts allowed to make an exogenously determined non-cash charge, $D^{a}$, against a's pre-tax cash flow. This charge could be thought of as depreciation or depletion. Asset a's taxable income is then $\left(C-D^{a}\right)$, and in the absence of other deductions its after-tax cash flow is $C-\tau\left(C-D^{a}\right)$, where $\tau$ is the applicable tax rate. ${ }^{1}$

Each member, 1, of a set of individual investors is endowed with initial wealth, consisting of some amount of tangible assets. The investors efther trade these assets directly or package them in the form of securities before trading. Securfties, which represent indirect claims on tangtble assets, come in the form of corporate or personal debt and corporate stock. That is, an investor can issue his own debt securities against his personal tangible holdings, or he can organize a corporation to hold the tangibles and have the corporation issue securities. Each investor's objective is to end up with a portfolio of tangibles and/or securities that maximizes his future consumption. Equivalently, such a portfolto will maximize the investor's after-tax cash flow.

The after-tax cash flow that is ultimately produced by a given tangible asset depends both on the form in which it is packaged and on its final owner. If asset a is owned directly by investor 1 , its income is taxed at 1 's exogenously spectfied personal tax rate, $\tau_{p}^{1}$, and the asset's 
after-tax cash flow is $C-\tau_{p}^{i}\left(C-D^{a}\right)$. We refer to any such directly held tangible as being packaged in partnership form. ${ }^{2}$

All tangibles held in corporate form are subject to corporate tax at the rate $\tau_{c}$. Whether they are subject to further personal tax depends on how the corporations finance them. We assume, following Miller (1977), that investors' returns on corporate stock are tax exempt. An asset packaged as corporate stock thus escapes double taxation, and its after-tax cash flow is simply $C-\tau_{c}\left(C-D^{a}\right)$.

By contrast, all interest on bonds is assumed to be taxable to the bondholder and tax deductible to the issuer. If an-asset is packaged as corporate debt, therefore, we must divide its cash flows into interest and principal payments. If an asset is to be fully debt financed, a corporation can promise after-corporate-tax debt service payments that exactly match the asset's after-corporate-tax cash inflows. Thus if the asset's value in this form is $v_{B}^{a}$, the interest payment at rate $r$, is $r V_{B}^{a}$ and the principal payment is $C-\tau_{c}\left(C-D^{a}\right)-r\left(1-\tau_{c}\right) v_{B}^{a}$. Since principal payments are tax exempt to bondholders, this leaves total after-tax receipts for investor $i$ of $r\left(1-\tau_{p}^{1}\right) v_{B}^{a}+C-\tau_{c}\left(C-D^{a}\right)-r\left(1-\tau_{c}\right) v_{B}^{a}$. Investors' packaging and trading activities produce market values for all tangible asset packages. In conjunction with the after-tax cash flows described above, these market values in turn define after-tax rates of return. For example, if investor $i$ holds asset a in partnership form, his after-tax return, $\rho_{p}^{a i}$, is given by

$$
v_{P}^{a}=\frac{c-\tau_{p}^{i}\left(c-D^{a}\right)}{1+\rho_{p}^{a i}},
$$

where $v_{p}^{a}$ is a's market value in this form. 
Analogously, i's after-tax return from holding a in corporate stock form is given by

$$
v_{S}^{a}=\frac{C-\tau_{c}\left(C-D^{a}\right)}{1+\rho_{S}^{a 1}}
$$

and in corporate bond form by

$$
V_{B}^{a}=\frac{C-\tau_{c}\left(C-D^{a}\right)+r\left(1-\tau_{p}^{1}\right) V_{B}^{a}-r\left(1-\tau_{c}\right) v_{B}^{a}}{1+\rho_{B}^{a 1}}
$$

Several features of these definitions are worth noting. First, from (2) corporate stock yields the same after-tax return to any investor. This is of course true of all tax-exempt securities.

Second, the after-tax cash flow from any tangible asset package can be represented as the asset's pre-tax cash flow, $C$, minus the net tax payments attributable to the asset in that form. This is obvious for partnerships and corporate stock from (1) and (2). It can be seen for corporate bonds if we rewrite (3) as

$$
V_{B}^{a}=\frac{C-\left[\tau_{c}\left(C-D^{a}\right)-\left(\tau_{c}-\tau_{p}^{i}\right) r V_{B}^{a}\right]}{1+\rho_{B}^{a i}},
$$

where the second term in the numerator is the net tax payment term. In the absence of debt financing, tax payments would be $\tau_{c}\left(C-D^{a}\right)$, as in (2). However, if $\tau_{c}>\tau_{p}^{1}$, debt financing generates a net tax shield and the tax payments attributable to the asset are reduced. ${ }^{3}$

Third, if a bond pays interest at the market rate, $r$, its market value is equal to its principal and we can further interpret (3). If

$$
v_{B}^{a}=C-\tau_{c}\left(C-D^{a}\right)-r\left(1-\tau_{c}\right) v_{B}^{a},
$$


then substituting (5) into (3) results in

$$
\rho_{B}^{a 1}=r\left(1-\tau_{p}^{1}\right)
$$

That 1s, any bondholder's after-tax return is equal to the after-tax Interest rate. Moreover, from (5)

$$
v_{B}^{a}=\frac{C-\tau_{c}\left(C-D^{a}\right)}{1+r\left(1-\tau_{c}\right)}
$$

That is, the value of an asset in corporate bond form, paying the market Interest rate, is equal to the asset's after-corporate-tax cash flow discounted at the after-corporate-tax interest rate. ${ }^{4}$

Faced with this set of conditions, Investors package and trade assets, as permitted by the tax authorities, unt1l the following equiI1brium is reached: 5

Definition: Asset market equilibrium consists of (a) an ownersh1p form or package (e.g., partnersh1p, corporate debt, corporate stock) for each tanglble asset, (b) a market value for each asset package and (c) an allocation of asset packages among Investors such that (1) asset and securfties markets clear and (2) at current market prices, no investor can alter his portfollo (e.g., trading or repackaging assets) in such a way as to Increase h1s after-tax return.

Equivalently, each tanglble asset must be packaged and allocated to a final investor in such a way that its value is maximized. This follows the basic logic of the Fisher Separation princlple: regardiess of his personal preferences or tax status, any Investor will want to package 
the tangibles he is endowed with in the way that maximizes his future consumption opportunities.

In deriving subsequent results, we will also find it useful to invoke the following equivalent concept of equilibrium:

Proposition I: A configuration of tangible asset packages, final owners and market values is an equilibrium if and only if it minimizes total future tax payments relative to the set of feasible, mutually voluntary transactions.

Proof: The configuration in question defines a market value, $v^{i}$, for each investor's net worth and an after-tax return, $\rho^{1}$, on that net worth. Total after-tax cash flow in the economy, then, is simply the sum, $\Sigma v^{i}\left(1+\rho^{i}\right)$, of cash returns across investors. Equivalently, the 1 economy's total wealth consists of the sum of tangible asset packages. Each such package, as we have seen, generates a pre-tax cash flow, $C$, minus the net tax payments, $T^{a}$, attributable to that package. Since summing across all asset packages would also give us the economy's total after-tax cash flows, we must have

$$
\sum_{i} V^{i}\left(1+\rho^{i}\right)=\underset{a}{\sum}\left(C-T^{a}\right)
$$

Suppose now that the ownership configuration is not an equilibrium. Then some investor $j$ can trade at current market prices in such a way as to Increase $\rho^{j}$ to $\rho^{f^{\prime}}$. Since all trades are voluntary, this could not result in a lower return on net worth for any other investor. After the trade, we must have 


$$
\sum_{1 \neq j} v^{1}\left(1+\rho^{1}\right)+v^{j}\left(1+\rho^{j}\right)>\sum_{1} v^{1}\left(1+\rho^{j}\right) .
$$

Equivalently, total after-tax cash flows after the trade are equal to the sum across asset packages, where $T^{a^{\prime}}$ represents the post-trade taxes attributable to asset a. Thus from (9)

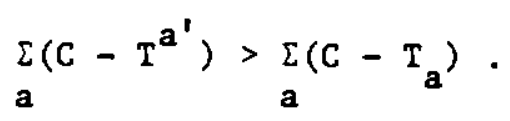

Since total pre-tax cash flows are unchanged, (10) holds only if $\sum T^{a^{\prime}}<\sum T^{a}$. This proves that any non-equilibrium ownership configuration a a fafls to minimize total taxes.

Now consider an ownership configuration that does not minimize taxes. Then there is some feastble transaction that investors will voluntarily undertake that reduces total taxes. Since the transaction is voluntary, no investor's after-tax return is reduced by tt. From (8), at least one investor's after-tax return is increased by this transaction. Therefore the initial configuration could not hve been an equilibrium. This completes the proof.

\section{2b. Asset packaging in the corporate sector}

Given the basic structure of the model, we can now describe the equilibrium allocation of tangtbles between partnership and corporate form and the financing of those tangibles held in the corporate sector. We begin with the latter question, which has been analyzed by Miller (1977).

If we assume temporarfly that al? tangtbles are held in corporate form, our model is equivalent to Mfller's, and we can make use of his findings. Three of his results are noteworthy in our context. 
First, if $r$ is the pre-tax return on debt, the equilibrium after-tax return on equity must be $r\left(1-\tau_{c}\right)$. Thus, the market value of any tangible packaged as corporate equity is given by

$$
v_{S}^{a}=\frac{C-\tau_{c}\left(C-D^{a}\right)}{1+r\left(1-\tau_{c}\right)}
$$

If this were not the case, then from (7) some entrepreneur could increase his portfolio return by repackaging equity as debt or vice versa. ${ }^{6}$

Second, while the total equilibrium supply of equity must be that which drives the after-tax return to $r\left(1-\tau_{c}\right)$, it doesn't matter which specific assets are packaged as equity or debt. Comparison of (11) and (7) Indicates that an asset must have the same market value in either form.

Third, in the absence of uncertainty, investors have specialized portfollos. From (6), any bondholder earns an after-tax return of $r\left(1-\tau_{p}^{1}\right)$, while any equityholder earns $r\left(1-\tau_{c}\right)$. Therefore no investor with $\tau_{p}^{1}>\tau_{c}$ can hold bonds, while no investor with $t_{p}^{i}<\tau_{c}$ can hold stock in equilibrium, since they would not be maximizing their after-tax return if they did.

\section{2c. Partnerships}

We can now relax the assumption that all tangibles are held in the corporate sector. In that event, there are two cases in which Investors can increase their after-tax returns by shifting an asset from corporate to partnership form. The first of these is described in the following proposition: 
Proposition II: If an asset's allowed depreciation, $D^{a}$, is such that $C<D^{a}$, it must be held in partnership form in equilibrium as long as there are any investors with $\tau_{p}^{1}>\tau_{c}$ holding corporate equity.

Proof: If any such asset is held in corporate form, whether debt or equity, its value must be

$$
v^{a}=\frac{C-\tau_{c}\left(C-D^{a}\right)}{1+r\left(1-\tau_{c}\right)}
$$

An Investor with $\tau_{p}^{1}>\tau_{c}$ who owns equity is earning an after-tax return of $r\left(1-\tau_{c}\right)$. If this investor were to purchase asset a for $v^{a}$ and repackage it as a partnership, his after-tax return would be

$$
\frac{C-\tau_{p}^{1}\left(C-D^{a}\right)}{v^{a}}-1>\frac{C-\tau_{c}\left(C-D^{a}\right)}{v^{a}}-1=r\left(1-\tau_{c}\right) .
$$

Thus he could increase his after-tax return by undertaking this transaction.

Conversely, if $i$ holds a in partnership form initlally, its value must be at least $v^{a}$ and $i$ must be earning an after-tax return of at least $r\left(1-\tau_{c}\right)$. If 1 switches to corporate equity, his after-tax return w11l at best remain unchanged. In addition, if asset a is repackaged in corporate form 1 ts after-tax return will be at most $r\left(1-\tau_{c}\right)$ (equity) or $r\left(1-\tau_{p}^{1}\right)$ (debt). Since these returns were already avallable on other corporate securitles, no Investor's position is improved if a is repackaged. Therefore, partnership form is the equilibrium package for a. This completes the proof. 
Assets with $C<D^{a}$ have been termed "negatively taxed" by Bailey (1974). Their allowed deductions are such that, as long as the owner has other income to offset, their after-tax cash flow exceeds their pre-tax cash flow. This is the principle that lies behind oil and gas drilling partnerships as well as various real estate, motion picture, research and development and other tax shelter investments sold in partnership form. Intuitively, one would expect such negatively taxed assets to be most attractive to investors in the highest tax brackets. This intuition is confirmed and generalized to any assets held in partnership form, whether negatively taxed or not, in the following proposition:

Proposition III: If two assets are held in partnership form by two investors with unequal tax rates, the asset with the larger allowed deductions must be held in equilibrium by the investor with the higher personal tax rate.

Proof: Suppose assets $a$ and $b$, with $D^{a}>D^{b}$ are held in partnership form. Suppose initially that investor 1 holds asset b while Investor $j$ holds asset a and $\tau_{p}^{1}>\tau_{p}^{j}$. The after-tax rates of return for investors $i$ and $j$ are thus defined implicitly by

$$
\begin{aligned}
& v_{P}^{b 1}=\frac{C\left(1-\tau_{p}^{1}\right)+\tau_{p}^{i} D^{b}}{1+p^{1}} \\
& v_{P}^{a j}=\frac{C\left(1-\tau_{p}^{j}\right)+\tau_{p}^{j} D^{a}}{1+p^{j}} .
\end{aligned}
$$


Hence Investor 1 could pay the following amount for asset a and still earn the same after-tax rate of return:

$$
v_{P}^{a 1}=\frac{C\left(1-\tau_{p}^{1}\right)+\tau_{p}^{1} D^{a}}{1+\rho^{1}}
$$

Similarly investor $j$ could pay the following amount for asset $b$ :

$$
v_{P}^{b j}=\frac{C\left(1-\tau_{p}^{j}\right)+\tau_{p}^{j} D^{b}}{1+\rho^{j}} .
$$

For the current ownership pattern to be an equilibrium, it must be that

$$
\frac{v_{P}^{b 1}}{v_{P}^{a 1}} \geq \frac{v_{P}^{b j}}{v_{P}^{a j}}
$$

Otherwise exchange is mutually preferable. But (16) can be shown to be equivalent to $\left(D^{b}-D^{a}\right)\left(\tau_{p}^{i}-\tau_{p}^{j}\right) \geq 0$, which is false. The condition is satisfled only if investor $i$ holds asset a and investor b holds asset $j$. Thus equilibrium can occur only if the high-tax bracket investor holds the high-deduction asset to the extent of his ability to do so. This completes the proof.

In the last line of the above proof, the phrase "to the extent of his ability to do so" deserves some clarification. If tax arbitrage were permitted, investors in the very highest tax bracket would hold all of the negatively taxed assets in equilibrium. If such an asset were held by an . Investor with any lower tax bracket, the high tax bracket investor would issue personal debt to buy it. Not only would this reduce taxes (or increase tax credits) attributable to the asset itself, but the interest deduction to the debt issue would always outweigh any additional taxes pald 
by the debt holder. With tax arbitrage restrictions, however, the highest tax bracket investors have limited ability to keep acquiring assets.

In the latter event, Proposition III implies that a sorting equilibrium will develop. If we rank investors in descending order of $\tau_{p}^{i}$ and assets in descending order of $D^{2}$, the investor with the highest $\tau_{p}^{i}$ will keep acquiring assets in descending order of $D^{a}$ until he runs up against the tax arbitrage constraint. The process is then repeated for the investor with the next highest tax rate and so on, until either the supply of negatively taxed assets is exhausted or we reach an investor with $\tau_{p}^{i}=$ $\tau^{c} c$ From (12) and (13), such an investor would be just indifferent between holding a negatively taxed asset in partnership or corporate equity form. Besides negatively taxed assets held by high tax bracket investors, there is a second case in which greater value can be achieved by packaging an asset in partnership rather than corporate form. This arises at the opposite end of the allowed deduction spectrum.

Proposition IV: Any asset with $\mathrm{D}^{\mathrm{a}}<\mathrm{C} /(\mathrm{l}+\mathrm{r})$ must be held in partnership form in equilibrium as long as there are investors with $\tau_{p}^{1}<\tau_{c}$ holding bonds.

Proof: Suppose such an asset were packaged in corporate debt form. ${ }^{7}$ Any investor with $\tau_{p}^{1}<\tau_{c}$ who held bonds would be willing to buy the asset in this form at its market price $v_{B}^{a}$. From (4), (6) and (7) the investor would earn an after-tax return of $r\left(1-\tau_{p}^{i}\right)$ on this asset, expressible as follows: 


$$
\rho_{B}^{a 1}=r\left(1-\tau_{p}^{i}\right)=\frac{C-\left[\tau_{c}\left(C-D^{a}\right)-\left(\tau_{c}-\tau_{p}^{1}\right) \frac{\left(C-\tau_{c}\left(C-D^{a}\right)\right)}{1+r\left(1-\tau_{c}\right)}\right]}{v_{B}^{a}}-1 .
$$

If this investor switched the asset to partnership form, his after-tax return would be:

$$
\rho_{P}^{a 1}=\frac{C-\tau_{p}^{1}\left(C-D^{a}\right)}{v_{B}^{a}}-1
$$

Subtracting (17) from (18):

$$
\rho_{P}^{a 1}-\rho_{B}^{a 1}=\frac{\left(\tau_{c}-\tau_{p}^{1}\right)\left[C-(1+r) D^{a}\right]}{\left[1+r\left(1-\tau_{c}\right)\right] v_{B}^{a}} .
$$

Since (19) is positive for $\mathrm{D}^{\mathrm{a}}<\mathrm{C} /(1+\mathrm{r})$, the asset cannot be held in corporate form in equilibrium.

Conversely, if the asset were held in partnership form, its value must be at least $\mathrm{v}_{\mathrm{B}}^{\mathrm{a}}$ and 1 ts owner must be earning an after-tax return of at least $r\left(1-\tau_{p}^{1}\right)$. Consequently, there is nothing to be gained by switching the asset to corporate form. This completes the proof.

Further insight into Proposition IV may be gained if we note that $D^{a}<C /(1+r)$ implies ${ }^{8}$

$$
C>D^{a}+\tau \frac{\left[C-\tau_{c}\left(C-D^{a}\right)\right]}{1+r\left(1-\tau_{c}\right)} \text {. }
$$

The right-hand side of (20) is simply the total tax deductions available against asset a when it is packaged in corporate debt form. These consist of depreciation and the interest on the corporation's debt. 
When (20) holds, these deductions are insufficient to shield the asset's entire pre-tax cash flow, $C$. If held in corporate debt form, then, the asset generates a positive tax liability at the corporate level and again at the investor level. Under these circumstances the partnership form, which eliminates double taxation, is advantageous. ${ }^{9}$ This is precisely the argument that has been used in support of the royalty trust concept, whereby a corporation spins off an income-producing property to its shareholders. The property's income is then taxable to the shareholders directly, as in a partnership, but corporate tax is avoided. It should be noted, though, that it is not sufficient to have $\tau_{p}^{i}<\tau_{c}$ in order for the royalty trust form to yleld tax advantages. It is also necessary that the assets held in trust be low depreciation assets (i.e., $D^{a}<C /(1+r)$ ). Since assets with $D^{a}<C /(1+r)$ are more heavily taxed than those with higher allowed deductions, it seems that they would be most efficiently held by investors in the lowest tax brackets. In fact, if the investors in the lowest tax bracket can borrow, they will hold all such assets in equilibrium:

Proposition V: Let $\tau_{\mathrm{p}}^{\mathrm{min}}$ be the minimum personal tax rate. In equilibrium, all assets with $D^{a}<c /(1+r)$ must be held in partnership form by investors whose tax rate is $\tau_{p}^{m i n}$ as long as these investors can borrow without limit.

Proof: We know from Proposition IV that all such assets must be held in partnership form by investors with $\tau_{p}^{1}<\tau_{c}$. Let asset a be held by investor $i$ with $\tau_{p}^{m i n}<\tau_{p}^{i}<\tau_{c}$. The asset's value, $v^{a}$, must be such that 


$$
v^{a} \leq \frac{C-\tau_{p}^{i}\left(C-D^{a}\right)}{1+r\left(1-t_{p}^{i}\right)}
$$

Otherwise, investor 1 could have earned a higher after-tax return by holding bonds. If an investor with tax rate $\tau_{p}^{\text {min }}$ borrows $v^{a}$ at interest rate $r$ from investor $i$ to purchase the asset, the difference, $\Delta T^{a}$, in total taxes attributable to asset $a$ is

$$
\Delta T^{a}=\tau_{p}^{i}\left(C-D^{a}\right)-\left[\left(C-D^{a}\right) \tau_{p}^{m i n}-r V^{a}\left(\tau_{p}^{i}-\tau_{p}^{m i n}\right)\right] .
$$

From (21),

$$
\begin{aligned}
\Delta T^{a} & \geq\left(\tau_{p}^{i}-\tau_{p}^{m i n}\right)\left\{\left(C-D^{a}\right)-I \frac{\left[C-\tau_{p}^{i}\left(C-D^{a}\right)\right]}{1+r\left(1-\tau_{p}^{1}\right)}\right\} \\
& =\left(\tau_{p}^{i}-\tau_{p}^{m i n}\right)\left[\frac{C-D^{a}(1+r)}{\left(1+r\left(1-\tau_{p}^{1}\right)\right.}\right]>0 .
\end{aligned}
$$

Thus, total taxes are always reduced by this transaction. This completes the proof. 10

Finally, if the lowest tax investors are limited in their ability to borrow, the logic of Proposition III dictates a sorting equilibrium. Investors in the lowest tax bracket will purchase assets beginning with those having the lowest $\mathrm{D}^{\mathrm{a}}$ and working up in ascending order of $\mathrm{D}^{\mathrm{a}}$. Once these investors' ability to purchase assets is exhausted, the process continues with the investor having the next highest tax rate and so on unt1l either the supply of assets with $D^{a}<C /(1+r)$ or the wealth of investors with $\tau_{p}^{1}<\tau_{c}$ is exhausted.

$$
\text { Together, Propositions I-V plus Miller's (1977) analysis }
$$

completely characterize the asset market equilibrium. Assets with the very 
highest and lowest allowed deductions will be organized as partnerships and sold to investors with the highest and lowest tax rates, respectively. In the face of borrowing restrictions, these partnerships will be sorted, with those having the highest deductions going to investors with the highest tax rates and vice versa. All remaining assets with $C /(1+r)<D^{a}<C$ will be held in corporate form. All such assets have the same value, so there is no sorting of assets within the corporate sector. However, the total of debt and equity financed assets must be such that the marginal bondholder has $\tau_{p}^{1}=\tau_{c}$.

\section{The Multiperiod Case}

As long as investors can costlessly trade or repackage assets each period, equilibrium in a multiperiod setting can be viewed as a sequence of single-period equilibria. In that event, many of the results of Section 2 carry over to the multiperiod case with only minor modification.

We assume in this section, therefore, that any investor or corporation can hold an asset for one period, collect that period's after-tax cash flow, and then sell or repackage the asset with no taxable recognition of gatns or losses and no recapture of depreciation. Although a complete equilibrium analysts of capital gains and recapture taxes is beyond the scope of this paper, we do consider some of their consequences in Section 6.

Under the frictionless repackaging assumption of this section, an asset's ownership form can be optimized perfod-by-pertod. Moreover, each asset's end-of-perfod market value is independent of its current owner and ownership form. In the aggregate, therefore, the configuration of asset 
ownership will be rearranged each period so as to minimize total taxes for that period.

In this environment, three analogues to the results of Section 2 are worth noting. Because they follow the same logic developed in that section, we state them here without proof.

First, if $C_{1}$ and $D_{1}^{a}$ are asset $a^{\prime}$ 's pre-tax cash flow and allowed deduction, respectively, in the most immediate future period, the asset will be held in partnership form during this period as long as $C_{1}<D_{1}^{a}$ and there are investors with $\tau_{p}^{1}>\tau_{c}$ holding corporate equity. Thus if an asset is negatively taxed even for only one period, it will be sold as a partnership to high tax bracket investors during that period.

Second, if the maximum corporate tax deductions (depreciation plus interest) for an asset in a given period are less than that period's pre-tax cash flow, the asset wust be held in partnership form during that period as long as there are investors with $\tau_{p}^{1}<\tau_{c}$ holding bonds. Stated In algebraic form, analogous to equation (20), the partnership condition is

$$
c_{1}>D_{1}^{a}+r \frac{C_{1}-\tau_{c}\left(C_{1}-D_{1}^{a}\right)+v_{1}^{a}}{1+r\left(1-\tau_{c}\right)}
$$

where $I$ is the one-period market interest rate and $v_{1}^{a}$ is the asset's end-of-period market value. The asset's future value enters this condition because if an owner can borrow against that value, it affects the size of avallable interest deductions in the most immediate future period. Rearranging and simplifying expression (24) results in the following analogue to the condition stated in Proposition IV:

$$
\mathrm{D}_{1}^{\mathrm{a}}<\frac{\mathrm{C}_{1}-r \mathrm{v}_{1}^{\mathrm{a}}}{1+\mathrm{r}}
$$


Th1s suggests that the larger is an asset's future value relative to its current cash flow, the less likely it is to be held in partnership form by low tax bracket investors. As we discuss further in Section 5 , the best candidates for low tax bracket partnerships, or royalty trusts, are assets whose future value is declining relative to current pre-tax cash flow.

$$
\text { Finally, if }\left(C_{1}-r V_{1}^{a}\right) /(1+r)<D_{1}^{a}<C_{1} \text {, the asset will be held }
$$

In corporate form during that next period. As in Miller (1977), the aggregate debt and equity financing of these corporate assets will be such that the marginal holder of either type of security earns a one-period return of $r\left(1-\tau_{c}\right)$. Hence the current value, $v_{0}^{a}$, of any corporate asset, whether debt or equity financed, is given by

$$
v_{0}^{a}=\frac{C_{1}-\tau_{c}\left(c_{1}-D_{1}^{a}\right)+v_{1}^{a}}{1+r\left(1-\tau_{c}\right)} .
$$

\section{Leasing}

The analysis thus far provides a new perspective on leasing, which has previously been recognized as a device for separating asset ownership from asset management. 11 It may be, for example, that an asset can generate its maximum pre-tax cash flows only if 1 is managed by a specific person or entity. However, the same cash flows and assoclated tax deductions may be worth more if they are owned by someone else. In such cases, where the optimal owner of an asset differs from its optimal manager, a potentially profitable lease transaction is available.

In this context, the analysis of Sections 2 and 3 can be thought of as identifying the optimal owner of any tangible asset. In the one-period case, for example, we have seen that assets with $C<D^{a}$ or $D^{a}<C /(1+r)$ are optimally held directly by investors in partnership form. 
If the same asset is most efficlently managed by a corporation, the investor-owners could simply lease it to the corporation. ${ }^{12}$ If $C /(1+r)<D^{a}<C$, on the other hand the asset is optimally owned in corporate form. Leasing can arise for such assets when they are best managed by an entity whose tax rate is other than $\tau_{c}$ (say, another corporation that finds itself in a nontax-paying position). 13

The fact that optimal asset owners can span the whole range of tax brackets highlights a point made by Myers, D1ll and Bautista (1976): Sometimes it pays for a low tax bracket entity to lease from a high tax bracket owner, but other times the reverse is true. The direction in which the transaction goes is determined by the tax bracket of the optimal manager and the magnitude of the asset's avallable deductions (depreciation, interest, etc.) relative to its pre-tax cash flow.

\section{A Life Cycle Model of Ownership}

While the mulitperiod case, discussed in Chapter 3, implicitly incorporates changes in cash flows and allowed deductions over time, we have not thus far taken the typical pattern of these changes into account. For many assets, both pre-tax cash flows and depreclation tax shields tend to decline over the asset's 1ffe. However, with accelerated depreciation, allowed deductions often decline at a faster rate than the pre-tax cash flows. Such assets may follow a natural ownership life cycle.

For example, when it is young a tangible asset may be negatively taxed, in which case it should be owned by investors whose tax rates exceed the corporate rate. When it is middle-aged, depreciation tax shields have declined and the asset may be positively but 1ightly taxed. In this phase, corporate ownership will be optimal. When it is old, depreciation tax 
shields have declined further and borrowing against the asset's future value no longer provides as much of an interest tax shield. The asset has thus become heavily taxed and should be owned in partnership form by investors with low tax rates--e.g., as a royalty trust.

These principles can be demonstrated with a simple model of the optimal ownership decision. Since this is a dynamic optimization problem, it is natural to formulate it in a continuous-time framework. As before, we abstract from uncertainty, although the model could be generalized in that direction.

Assume that the pre-tax cash flow $C(t)$ grows at a constant rate g, namely

$$
\mathrm{dC} / \mathrm{C}=\mathrm{gdt} \text {. }
$$

We assume that the pre-tax cash flow declines through time--1.e., $g<0$. Let $B(t)$ be the tax basis of the asset, and let depreciation (and depletion) be at $a$ constant proportional rate $\delta$. Thus depreciation is $D(t) \equiv \delta B(t)$ and $1 t$ evolves according to

$$
\mathrm{dD} / \mathrm{D}=\mathrm{dB} / \mathrm{B}=-\delta \mathrm{dt} \text {. }
$$

The extent to which the pre-tax cash flow is sheltered from taxation is summarized by the ratio of depreciation to pre-tax cash flow $Y(t) \equiv D(t) / C(t)$, which evolves according to

$$
d \gamma / \gamma=-(\delta+g) d t
$$

A typical tangible asset becomes more heavily taxed through time--1.e., $\delta>-g$ and thus $\gamma$ declines through time. 
The life cycle for the ownership of the asset can be summarized by the value of the ratio $\gamma$. We know that as long as $\gamma>1--i . e$. , $D(t)>C(t)-$ the asset is negatively taxed and thus should be owned in partnership form by 1nvestors above the corporate tax rate. We expect that where $\gamma=1$ the asset should be repackaged into corporate form. We also expect that the asset should eventually be converted into a low-tax royalty trust. Evidently there is a critical value $\gamma^{*}<1$ where it is optimal to convert the asset from corporate to royalty trust form. This life cycle is summarized in Exhibit 1.

Exhibit 1

\section{Life Cycle for Ownersh1p of Tangible Assets}

$\begin{array}{ccc}\frac{\text { Youth }}{Y>1} & \text { Middle Age } & \text { 01d Age } \\ \begin{array}{ccc}\text { high tax } \\ \text { partnership }\end{array} & 1>\gamma>\gamma^{*} & \gamma^{*}>\gamma \\ & \text { corporation } & \begin{array}{c}\text { royalty } \\ \text { trust }\end{array}\end{array}$

It remains to identify the critical ratio $\gamma^{*}$. Assume for now that all royalty trusts are owned by nontaxable investors. (Remember that royalty trusts should be held by investors in tax brackets at least as low as those of corporate bondholders, and that most corporate bonds are held by nontaxable institutions). Hence the value of a royalty trust $R(t)$ is given by capitalizing its pre-tax cash flows at the pre-tax interest rate:

$$
R(t)=\int_{t}^{\infty} C(s) e^{-r(s-t)} d s=C(t) /(r-g) .
$$

Now consider the value of the asset while it is still in corporate form. The after-corporate-tax operating cash flows are $X(t) \equiv\left(1-\tau_{c}\right) C(t)+\tau_{c} D(t)$. At the optimal time $t *$ the corporation w111 
convert the asset into a royalty trust with value $R\left(t^{*}\right)$. The value of the asset while still in corporate form $V(t)$ is given by capitalizing these cash flows at the after-corporate-tax interest rate:

$$
\begin{aligned}
V(t)= & \int_{t}^{t *} X(s) e^{-r\left(1-\tau_{c}\right)(s-t)} d s+e^{-r\left(1-\tau_{c}\right)\left(t^{*}-t\right)} R\left(t^{*}\right) \\
= & \left(1-\tau_{c}\right) C(t)\left[1-e^{-\lambda\left(t^{*}-t\right)}\right] / \lambda+\tau_{c} D(t)\left[1-e^{-\mu\left(t^{*}-t\right)}\right] / \mu \\
& +C(t) e^{-\lambda(t *-t)} /(r-g)
\end{aligned}
$$

where

$$
\lambda \equiv \mathbf{r}\left(1-\tau_{c}\right)-g \text { and } \mu \equiv \mathbf{r}\left(1-\tau_{c}\right)+\delta
$$

The optimal time t* to repackage the asset from corporate to royalty trust form maximizes the value of the asset. Hence we have the first order condition

$$
0=\partial V(t) / \delta t^{*}=\left(1-\tau_{c}\right) C\left(t^{*}\right)+\tau_{c} D\left(t^{*}\right)-\lambda C\left(t^{*}\right) /(r-g)
$$

which can be rewritten as

$$
C(t *) /(r-g)=X\left(t^{*}\right) /\left[r\left(1-\tau_{c}\right)-g\right]
$$

where the LHS is the value of the royalty trust and the RHS is the value of a notional asset in corporate form whose after-tax cash flows grow at the rate $g$.

An altemative, but instructive way to derive this condition is to consider net taxes paid as a result of keeping the asset in corporate form. Taxes before financing are $\tau_{c}(C-D)$. At the optimal conversion time, the value of the asset is given by the royalty trust valuation formula $\mathrm{C} /(\mathrm{r}-\mathrm{g})$. If the asset is financed with debt, the tax saving due to 
interest expense is $\tau_{c} r C /(r-g)$. At the optimal conversion time, the net tax effect is exactly zero:

$$
\tau_{c}[C(t *)-D(t *)]=\tau_{c} r C(t *) /(r-g) .
$$

It can be verified that (33) is equivalent to (32).

Note that the corporate tax rate can be eliminated from (33). Hence the optimal time to convert from corporate to royalty trust form is independent of the corporate tax rate. This result is reminiscent of our finding in the one-period case that the critical ratio of depreciation to pre-tax cash flow for determining ownership form is independent of tax rates.

We can solve (32) or (3) for the critical ratio $\gamma$ * that separates the corporate from the royalty trust stage:

$$
\gamma^{*} \equiv D(t *) / C(t *)=-g /(r-g)
$$

Note that this ratio only makes sense if $g<0$, when pre-tax cash flow declines through time. To understand why, consider the watershed perpetuity case where $g=0$. Assume first that depreciation is zero. Then (34) is identically zero and the asset is equally valuable in corporate or royalty trust form. For example, if the asset is financed in corporate form by an issue of debt, pre-tax cash flow is exactly sheltered by interest expense. In this case, corporate borrowing also eliminates double taxation and hence low-tax investors are indifferent between receiving the pre-tax cash flow directly through a royalty trust or indirectly through interest payments. Now introduce depreciation. The associated tax shields are more valuable to a corporation (or high-tax investors) than to low-tax investors. Hence the asset should never be owned in a low-tax royalty trust. 


\begin{abstract}
Similarly, when $g \geq 0$ interest expense is greater than or equal to pre-tax cash flow. Both the excess interest expense and the depreciation tax shields are more valuable in corporate (or high-tax partnership) form than in royalty trust form owned by low-tax investors. Thus royalty trusts only make sense for wasting assets, where $g<0$.

When $g<0$, the possibility of conversion increases the value of assets and thus the net present value associated with investment decisions. For example, consider the value of an asset in 1ts corporate stage. Since 1t can be shown that the critical ratio $\gamma^{*}$ occurs at time
\end{abstract}

$$
t *=t+\frac{\ln [\gamma * / \gamma(t)]}{g+\delta}
$$

we have from (31) that

$$
\begin{aligned}
V(t)= & \left(1-\tau_{c}\right) C(t) / \lambda+\tau_{c} D(t) / \mu \\
& +C(t)\left[\gamma(t) / \gamma^{\star}\right]^{\lambda /(g+\delta)} /(r-g)-\left(1-\tau_{c}\right) C(t)\left[\gamma(t) / \gamma^{\star}\right]^{\lambda /(g+\delta)} / \lambda \\
& -\tau_{c} D(t)\left[\gamma(t) /{ }^{\star}\right]^{\mu /(g+\delta) / \mu}
\end{aligned}
$$

The first two terms correspond to the value of the asset if it is kept in corporate form forever. Hence the last three terms represent the extra value due to the opportunity to convert the asset into a royalty trust. It would be nice to have a simple valuation expression for any asset which is inftially negatively taxed, while it is still in its high tax partnership stage. Unfortunately, this requires a knowledge of the sequence of investors who own these partnersh1ps, and their required rates of return. 14

One final point about royalty trusts is worth making, namely that creation of royalty trusts only makes sense for assets whose depreciated 
book value is less than current market value. To demonstrate this, consider the value of an asset held forever in corporate form, namely

$$
V(t)=\frac{\left(1-\tau_{c}\right) C(t)}{r\left(1-\tau_{c}\right)-g}+\frac{\tau_{c} \delta B(t)}{r\left(1-\tau_{c}\right)+\delta}
$$

Now suppose that depreclated book value equals current market value-$B(t)=V(t)$--and that the rate of depreciation equais the rate of decline In pre-tax cash flow: $\delta=-g$. Then this valuation expression simplifies to $B(t)=V(t)=C(t) /(r-g)=R(t)$. Since all variables grow at the same rate, this relation always holds. Hence book value always equals market value, and the value of an asset in corporate form is the same as in a royalty trust. This result corresponds to the special case where accountIng depreciation exactly equals economic depreclation. Myers, Dill and Bautista (1976) found that corporations were indifferent between leasing and buying in this case. In Section 4 we argued that their leasing analysis could be reinterpreted as a statement about optimal owners of assets--i.e., when accounting depreciation equals economic deprectation there is no optimal owner.

\section{It intuitively follows for the faster depreciation schedules} assumed here--1.e., $\delta>-g--$ that conversion to a royalty trust should be delayed until a subsequent time when depreciated book value is less than prevalling market value. To verify this, suppose the contrary, namely that It is optimal to convert now, so that, $D(t)=\delta B(t)=\delta V(t)=\delta R(t)=$ $\delta C(t) /(r-g)$. But then $\gamma(t) \equiv D(t) / C(t)=\delta /(r-g)>\gamma^{*}$. Hence it is too early to convert to a royalty trust. In summary, conversion to a royalty trust only makes sense when depreclated book value is less than current value. This result is reminiscent of our finding in the one-period case that royalty trusts only make sense if $D<C /(1+r)$. 
The analysis thus far explains how high tax partnerships and royalty trusts can dominate uninterrupted corporate ownership of tangible assets. However there may be other mechanisms which serve a similar purpose, particularly in the face of capital galns and recapture taxes. It is to this topic that we now turn.

\section{Mergers and Acquisitions}

We have seen that royalty trusts can be an effective mechanism for reducling taxes on a wasting asset like an oil fleld. However it has been claimed that mergers and acquistitions also accomplish the same thing, through the associated step-up in the tax basis of assets. Indeed U.S. Steel justifled 1ts $\$ 7$ billion acquisition of Marathon 011 in part on precisely this tax reduction. The relationship between royalty trusts and acquisitions as alternative mechanlsms for reducing taxes on wasting assets was highlighted by Mesa Petroleum's tender offer for Gulf 011 , and Gulf's subsequent acquisition by Socal for $\$ 14$ blll1on. Mesa's offer proposed to reorganize Gulf's oil-producing properties as royalty trusts specifically to reduce taxes.

Whether a royalty trust or an acquisition is the better way to reduce taxes on a wasting asset, and whether acquisitions of nonwasting assets yleld tax benefits, are questions that depend critically on the specifics of the tax code. (From the last section, we know that royalty trusts are not appropriate for nonwasting assets.) The mechanism and current tax law regarding creation of a royalty trust are as follows. First the corporation places certain of its assets in a trust. The tax basis of the trust is 1dentical to that of the assets. There is no taxable event upon creation of the trust. However there is a taxable event upon 
distribution of the beneficial interest in the trust to stockholders. The distribution is treated like any other dividend; it is taxed at ordinary income rates, calculated on the basis of the observed secondary market value of trust units.

In equilibrium, the effective tax associated with distribution of a royalty trust is likely to be minimal. Since low-tax investors are the logical owners of royalty trusts, it makes sense for them to purchase the stock just before distribution, so that the distribution is taxed at their rate. ${ }^{16}$ As mentioned in the last section, these investors are likely to be nontaxable. Hence the only taxes associated with such a distribution have to do with the recognition of capital gains by the original (high tax) stockholders. In keeping with the rest of the paper, we assume that the effective tax on capital gains is minimal. (For example, stockholders may be able to recognize offsetting losses.)

The mechanism and applicable tax law regarding an acquisition to step up the tax basis of assets are as follcws. ${ }^{17}$ The acquiring corporation purchases the stock of the acquired corporation, thus generating a capital gains liability for stockholders. (As before, we assume an effective capital gains tax rate of zero.) The acquiring corporation then "liquidates" the acquired corporation. 18 Under Section 334 of the Internal Revenue Code, the acquiring company is allowed to step up the tax basis of the assets of the acquired company to a level equal to the value of the consideration paid for the acquired company. However, under Section 1245 , the acquiring company is liable at ordinary income tax rates for recapture of any post-1962 depreciation. 
In the absence of capital gains taxation, an equivalent mechanism is for another corporation to purchase the asset directly from the corporation that currently owns 1t. In elther case there is a corporate tax on recapture.

The comparison between an acquisition and creation of a royalty trust as a mechanism for reducing taxes under current tax law thus depends on the relation of the current market value of an asset to its initial book value. Suppose first that the current market value of the asset, which incorporates its optimal tax treatment, is less than its initial book value. Then the acquisition mechan1sm actually increases taxes in present value terms. In other words, any reduction in taxes due to a step-up in basis is exactly offset by taxes paid due to recapture. Furthermore, the taxes paid because of recapture are due immediately, while the taxes saved because of the step-up in basis are sfread into the future. Hence, if current market value is less than initial book value, creation of a royalty trust is the approprlate way to reduce taxes on a wasting asset.

The polar alternative case is where initial book value 1 s trivial compared to current market value. For example, oil fields that were established before the dramatic increases in oil prices are likely to be in this situation. In this case, the tax due to recapture is trivial compared to the step-up in basis. Hence it is virtually costless to step up the basis to current market value. Furthermore, we know from the last section that royalty trusts do not make sense if book value is as large as current market value. Hence an acquisition creates more value than conversion to a royalty trust in this case.

To recapitulate, the tax advantages under current law of acquisitions versus conversions to royalty trusts depend on the relation between 
current market value and initial book value. If market value is below initial book value, conversion to a royalty trust is advantageous, but an acquisition is not. If market value is substantially above initial book value, the tax on recapture is small compared to the tax benefits associated with a step-up in basis; hence an acquisition dominates conversion to a royalty trust.

Our analysis also addresses the tax consequences of a sale and leaseback arrangement between corporations designed to step up an asset's basis. Such an arrangement can be decomposed into the sale part and the leaseback part. We argued in Section 4 that any perceived benefits in a lease were attributable to the asset being held by its optimal owner. Hence any net tax benefits have to do with the sale part. But we noted above that the tax consequences here were the same as with an acquisition of stock. Hence our use of the term acquisition can be considered to include assets sales as well, whether or not there is a leaseback arrangement.

Finally, we have seen that any advantage of a royalty trust relative to acquisition by another company under current law has to do with the avoidance of recapture--for example, when market value is below historic book value. Proposed tax law even eliminates this advantage for royalty trusts. According to this proposed law, the corporate tax consequences of creation of a royalty trust are the same as if the corporation had sold the asset, entalling recapture and capital gains. In this case, since the tax consequences to the corporation that initially owns the asset are the same, it makes sense for another corporation to buy the asset and step up its basis to market value. Hence, under proposed law, conversion to royalty trust is always dominated by acquisition. 


\section{Conclusion}

In this paper we have investigated the effect of taxes on the equilibrium ownersh1p structure of tangible assets. Th1s 1ssue encompasses the corporate capital structure decision, but 1t also includes the broader cholce between corporate and partnership form.

For some interesting special cases we are able to completely characterize the asset market equilibrlum. Subject to the qualifications discussed above, our basic results can be summarized as follows: negatively taxed assets are best held by high tax bracket investors, while positively taxed assets are best held by low tax bracket investors. All negatively taxed assets will thus be organized as high tax bracket partnerships. All assets that are positively taxed, ever after allowance is made for maximum corporate interest deductlons, will be organized as low tax bracket partnerships. All other assets will be held in corporate form, and their aggregate flnancing proportions will be consistent with Miller's (1977) equ1librium.

Other aspects of the problem remain to be studied in more detail. For example, in Section 6 we have only touched on the 1ssues posed by a realistic treatment of capital gains and recapture taxes.

A second major task would be to Integrate the incentive problem aspects of ownership structure with the tax considerations analyzed in this paper. As mentloned, Fama and Jensen (1983 $a$ and b) and Wolfson (1983) have discussed the relative severity of incentive problems entailed by the corporate and partnersh1p forms. The theory would be further advanced by a more detailed analysis of the trade-offs between economizing on taxes and mitigating incentive problems. 
FOOTNOTES

1. Alternatively, $D^{a}$ determines the fraction, $\left(1-\frac{D^{a}}{C}\right)$, of the asset's pre-tax cash flow that is taxable. Black (1971) refers to this taxable fraction as the asset's tax bracket.

2. We make no distinction between partnerships and sole proprietorships. For our purposes, the key feature of either form is that the asset is not subject to double taxation.

3. In similar fashion, if investor 1 holds asset a in partnership form and finances it by issuing personal debt to investor $j$, the value of the debt can be represented as

$$
v_{p}^{a}=\frac{c}{1+\rho_{B}^{a j}}-\frac{\left[\tau_{p}^{i}\left(C-D^{a}\right)-\left(\tau_{p}^{i}-\tau_{p}^{j}\right) r v_{p}^{a}\right]}{1+\rho_{B}^{a j}}
$$

Any chain of securities issues against a tangible asset can ultimately be expressed in the same general form.

4. The same rule also holds in the multiperiod case as Ruback (1983) has shown. Analogously, if investor $i$ issues personal debt against a directly held tangible asset, the value of this debt is given by

$$
v_{p}^{a}=\frac{C-\tau_{p}^{1}\left(C-D^{a}\right)}{1+r\left(1-\tau_{p}^{1}\right)}
$$

5. The authorities will limit tax-arbitrage transactions, which consist of investors taking simultaneous long and short positions in assets that are subject to different tax treatment. A prime example is borrowing by high tax bracket investors to purchase tax-exempt 
securities, such as equity. Some amount of these transactions can be admitted in our model, as they are in actual fact. What is necessary is that tax arbitrage not be allowed to eliminate all differences in after-tax yields across securities of different types and across investors in different tax brackets.

6. If corporations issue debt to repurchase equity, or vice versa, they are engaging in a kind of tax arbitrage. The ability of the corporate sector to undertake such transactions without limit, while individual investors cannot, is a fundamental determinant of equilibrium. If the investor with the highest personal tax rate, $\tau_{p}^{\max }$, could borrow without limit to purchase stock, all tangible assets would be packaged as stock, and all corporate stock would be held by this investor, who would finance his holdings by issuing personal debt to other investors. In that event, the equilibrium after-tax return on equity would be $r\left(1-\tau_{p}^{\max }\right)$.

7. Since the asset would have the same market value if it were packaged in corporate stock form, it is sufficient to examine the corporate debt case.

8. If $C>D^{a}(1+r), C-D^{a}>r D^{a}$. Adding and subtracting $r C$ and $I \tau_{c}\left(C-D^{a}\right)$ from the right-hand side of this inequality gives $C-D^{a}>-r\left(1-\tau_{c}\right)\left(C-D^{a}\right)+r\left(C-\tau_{c}\left(C-D^{a}\right)\right)$ which in turn 1mplies (20).

9. If an asset is held in corporate stock form, it of course generates positive tax liabilities at the corporate level but none at the investor level. A further implication of Proposition IV, then, is that it can be worthwhile to submit to the corporate tax only if the 
corporation's taxable Income is not "too large"; that is, only 1f $D^{a}>C /(1+r)$.

10. If there are tax-exempt 1nvestors, they will bid up the prices of these assets until their return is exactly $r$. This 1mplies that all such assets will have a value of $v_{p}^{a}=c /(1+r)$, in which case the partnersh1p condition is equivalent to $D^{a}<v_{P^{*}}^{a}$.

11. See Miller and Upton (1976), Lewellen, Long and McConnel1 (1976) and Myers, D111 and Baut1sta (1976) for more extens1ve discussions of leasing. Our conclusions are consistent with these authors. Our purpose here $1 \mathrm{~s}$ simply to show that the leasing question can be imbedded in the larger question of who should optimally own a given tanglble asset in equ1librium.

12. Alternatively, as 1s usually done in oil drilling or other tax shelter deals, the limited partners can sign a management contract with the general partner (frequently a corporation). Or under the royalty trust concept, a set of assets originally owned by a corporation could be spun off in trust to investors, but still managed under a contract by the corporate parent. Our analysis of course ignores all incentive problems resulting from separation of ownership and management. See Wolfson (1983) for a discussion of these problems in the context of dr1l11ng partnerships.

13. Myers, D111 and Baut1sta (1976) conclude that there 1s no net advantage to leasing in the one-perlod case. Th1s conclusion is driven by two assumptions that differ from ours: first, that any owner can borrow without restriction and second, that the asset's allowed depreciation, $D^{a}$, is equal to its purchase price $V^{a}$. Under their assumptions, for any owner (indlvidual or corporate) with tax rate $\tau^{*}$, it must be true that 


$$
\mathrm{V}^{\mathrm{a}}=\frac{\mathrm{C}-\tau *\left(C-\mathrm{V}^{\mathrm{a}}\right)}{1+r\left(1-\tau^{*}\right)}
$$

Solving for $v^{a}$ yields

$$
v^{a}=\frac{C}{1+r}
$$

and thus asset value is independent of the owner's tax rate. Intuitively, the disadvantage of debt for a wasting asset due to the fact that principal repayment is not deductible is exactly offset in this case by the advantage of depreciation, which exactly shelters principal repayments. While the assumption that $\mathrm{D}^{\mathrm{a}}=\mathrm{v}^{\mathrm{a}}$ is quite reasonable for depreciation, we construe $D^{a}$ to include other nondepreciation tax shields, so that their total need not sum to the asset's initial value.

14. If the maximum investor tax rate is equal to the effective corporate rate, then the valuation formula in (9) continues to be valid.

15. More specifically, the royalty trust distribution is considered a dividend if the parent corporation has accumulated surplus on its tax books. Otherwise, it is deemed a tax-free return of capital. See Cooper (1984).

16. In practice, large distributions like these (or payments of arrearages on preferred stock) are candidates for "dividend stripping" by corporations that take advantage of the intercorporate dividend exclusion and simultaneously recognize capital losses associated with the price decline. If this is allowed, equilibrium may not exist on the ex-dividend date.

17. There are two basic kinds of acquisitions: acquisitions that are "taxable" for stockholders, and acquisitions that are "tax-free" for 
stockholders. "Tax-free" acquisitions generate no capital gains llability for stockholders, but they also do not allow for a step-up in the tax basis of assets. The mechanism described here is a "taxable" acquisition, which generates both a capital galns liability and a step-up in the tax basis.

18. It is no longer possible to engage in a "partial 11quidation" of the acquired company, as U.S. Steel did in acquiring Marathon 011. This device allowed U.S. Steel to step up the tax basis of the Yates ofl fleld, without recognizing gains associated with Marathon's use of LIFO accounting. 


\section{REFERENCES}

ABRAMS, B., 1984, "Metromedia Officers to Raise $\$ 300$ Million by Assets Sale Once Buyout Is Completed," Wall Street Journal (April 30). BAILEY, M. J., 1974, "Progressivity and Investment Yieids Under U.S. Income Taxation," Journal of Political Economy, 82 (November/December), pp. 1137-75.

BLACK, F., 1971, "Taxes and Capital Market Equilibrium," Working Paper No. 21A, University of Chicago, Graduate Schooi of Business.

COOPER, W., 1984, "Decorporatizing Corporate Assets," Institutional Investor, 18 (May), pp. 171-6.

FAMA, E. F. and M. C. JENSEN, 1983a, "Separation of Ownership and Control," Journal of Law and Economics, 26 (June), pp. 301-25. , 1983b, "Agency Problems and Residual Claims," Journal of Law and Economics, 26 (June), pp. 327-49.

LEWELLEN, W. G., M. S. LONG and J. J. McCONNELL, 1976, "Asset Leasing in Competitive Capital Markets," Journal of Finance 31 (June), pp. 787-98.

MILLER, M. H., 1977, "Debt and Taxes," Journal of Finance, 32 (May), pp. $261-75$.

and C. W. UPTON, 1976, "Leasing, Buying and the Cost of Capital Services," Journal of Finance, 31 (June), pp. 761-86.

MYERS, S. D., D. A. DILL and A. J. BAUTISTA, 1976, "Valuation of Financial Lease Contracts," Journal of Finance, 31 (June), pp. 799-819.

RUBACK, R. S., 1983, "Calculating the Present Value of Riskless Cash Flows," Working Paper No. 1348-83, Sloan School of Management, M.I.T. 
WOLFSON, M. A., 1983, "Emptrical Evidence of Incentive Problems and Their Mitigation in $0 \pm 1$ and Gas Tax Shelter Programs," paper presented at 75th Anntversary Colloquium, "Asymmetric Information, the Agency Problem and Modern Bustness Practice," Harvard Business School. 